\title{
CONTRATOS SUSCRITOS POR LA ACADEMIA NACIONAL DE SAN CARLOS CON LOS PROFESORES JAVIER GAVALLARI, EUGENIO LANDESIO, SANTIAGO BAGGALLY Y JORGE A PERIAM
}

Eduardo Báez Hacias

En la historia de la Academia de Bellas Artes de San Carlos de México hubo dos momentos de intensa actividad artística: el inmediato a su real erección en 1783 y el que siguió a su reorganización bajo el gobierno de Santa Anna en 1843 Para el primero fue la esplendidez de Carlos III la que permitió, desde los inicios, traer directores seleccionados en la Academia de San Fernando de Madrid, de la importancia de Tolsá, Jimeno y Velázquez. Para el segundo, fue un feliz error de Santa Anna el que permitió una renovación completa, fincada en la contratación de profesores europeos que superaron el vacío en que se encontraban las artes plásticas, como consecuencia del abandono en que la tuvieron nuestros primeros gobiernos independientes y los escasos y a veces nulos recursos de sus arcas.

Santa Ana intentó la reorganización con su famoso decreto de 2 de octubre de 1843 que tenía previsto el contratar directores europeos; pero más importante fue su decisión de ceder a la Academia las rentas de la Lotería que, mal administradas, arrojaban más alcances que haberes. Y ésta fue la afortunada equivocación del dictador, al ceder una fuente de ingresos en quiebra que muy pronto, bajo la honrada y hábil administración de Javier Echeverría, principió a producir abundantes recursos. Entonces Santa Ana, cuya miopía no le permitía ver que el mayor de todos los males en nuestra historia ha sido la corrupción administrativa, intentó revocar la cesión de la Lotería y recuperar sus productos, siendo necesaria toda la habilidad y la influencia de personajes como Echeverría y Bernardo Couto para disuadirlo

Ya entonces se hacían las gestiones para contratar profesores europeos, con buenos sueldos, que sirvieran las direcciones de pintura, escultura y grabado. Para el caso de Manuel Vilar y Pelegrín Clavé, remito al lector a las biografias escritas por Salvador Moreno. ${ }^{1}$ En cuanto a los otros cuatro artistas que vinieron a revivir el ejercicio de las artes plásticas, me permito por ahora publicar los contratos que suscribieron con la Academia, como un primer paso en los más amplios estudios que merecen

- Moreno, Salvador Ll pmlor Pelegrin (la é México, Instituto de Investigaciones Estéticas de la LN 111.1960 y Kl wallor Mamul Jilar, Instituto de Investigaciones Estéticas de la UNA.11, 1969) 
Proceden estos documentos del archivo de la Antigua Academia de San Carlos, hoy depositado en la Escuela Nacional de Arquitectura de la Universidad Nacional Autónoma de México. ${ }^{2}$

Para el grabado en hueco se contrató a Santiago Baggally, en Londres, firmándose el contrato el 30 de abril de 1846 . Se estipuló un sueldo anual de seiscientas libras o tres mil pesos, con mil adelantados para el viaje y otros tantos de garantía para el regreso. Se pactó como plazo 5 años que empezaron a correr el 20 de julio siguiente, cuando el grabador llegó a México, y que antes de expirar fue renovado por otros cinco. Aunque la renovación aparece firmada por Bernardo Couto el 6 de noviembre de 1852, estaba surtiendo efectos desde el 20 de julio de 1851, pero no había sido firmada por la inesperada'muerte del entonces director Javier Echeverría.

Para el grabado en lámina se contrató a George Austin Periam, también en Inglaterra, por ser éste el país en donde más prestigio tenía el ramo de grabado. Se firmó el contrato el 14 de abril de 1853 , con un salario estipulado de tres mil dólares.

Para la dirección de arquitectura trajeron a Javier Cavallari, de la Academia de Milán, firmándose el contrato el 5 de septiembre de 1856 . Como representante de la Academia firmó Manuel Larrainzar, pactándose el mismo salario de tres mil pesos, como en las otras direcciones, que empezaria a correr en cuanto el arquitecto desembarcara en Veracruz. Durante el tiempo de su contrato se obligaba Cavallari a realizar dos obras para la Academia y un catálogo de los objetos propios de su ramo, y de la misma manera que los otros directores tuvo la tácita autorización para ejercer su profesión de ingeniero civil Su primer contrato debia terminar el 31 de diciembre de 1861, pero antes de vencer el plazo se hallaba ya prorrogado hasta el 31 de diciembre de 1862 . Es notable que entre sus obligaciones estaba el trabajo de campo con sus alumnos, para trazar caminos y construir puentes.

El cuarto documento es el contrato con Eugenio Landesio, suscrito el 2 de mayo de 1854 por Bernardo Couto y Pelegrín Clavé, que actuaba en representación del pintor italiano, y que éste ratificó el 10 de junio siguiente. El plazo fue el mismo de 5 años, pero se renovó varias veces, pues Landesio permaneció en México hasta 1873. No vino como director, sino como profesor de perspectiva, paisaje y principios de ornato, y por esta circunstancia su salario anual era de solamente mil quinientos pesos

\footnotetext{
${ }^{2}$ Báez M, Eduardo Guía del Archwo de la Anitgua Academza de San Carlos. 3a parte, 1844-1867 México, Instituto de Investigaciones Estéticas de la UNAM, 1974
} 


\section{DOCUMENTOS}

\section{CONTRATO CON JOHN JAMES BAGGALLY}

Articles of agreement made an entered into this thirlieth day of april 1846 between his Excellency don Tomas Murphy, Minister plenipotentiary for the Republic of Mexico at the court of Saint James, acting by and on behalf of the President of the National Academy of San Carlos in Mexico and his succesors of the one part and John James Baggally of No 8 Surrey Square old Hent Road London die sinker and engraver of the other part.

The said John James Baggally for himself, his heirs executors and administrators, doth covenant promise and agree to and with the said don Tomas Murphy acting for and on behalf of the President aforsaid and his succesors in manner following (that is to say). That for and in consideration of the sum of two hundred pounds in hand paid to him, the said john James Baggally by or on behalf of the President aforesaid for the expenses for his journey and voyage to Mexico, the capital of the Mexican Republic, in addition to the salary herein after mentioned and also in consideration of 600 pounds sent and advanced to the said John James Bagally on account of his said salary, the receipt of which said two sums the said John James Baggally doth hereby acknowledge and also in consideration of the yearly salary of 600 pounds or 3000 pesos to commence and be payable to him the said John James Baggally in periodical payments from and after his arrival in the territory of the Republic of Mexico; he the said John James Baggally shall and will proceed to Mexico so as to arrive there on or before the thirty first day of July next and faithfully and diligently serve the said President and his succesors in the National Academy of San Carlos at Mexico in the practice profesion or bussines of Die sinker and engraver during the term of 5 years to be reckoned from the above stated time of his arrival in the mexican territory and from thence next ensuing and fully to be complete and ended and in such service he the said John James Baggally shall and will (according to the best of his skill knowledge an ability) work and labor and also teach and instruct all such other persons in the art of the sinking and engraving, as the said President or other proper authority of the said Academy shal! require. And he the said John James Baggally doth hereby contract and agree as aforsaid that during the said term of five years he shall and will readily and cheerfully obey and execute all reasonable and proper demands of the President and his succesors, for the time being or other proper authority of the said Academy and shall not nor will absent himself or depart from the said service or employ without proper license and consent fot that purpose first obtained, and will conduct himself in his said employ with diligence and in all things serve the said 
Academy as a faithfull servant thereof. And the said Tomas Murphy by and on behalf of the said President and his succesors doth hereby contract and agree that the said John James Baggally, in all things keeping his said covenant and agreement shall be taken and accepted in the service of the said Academy aforesaid for the periord of five years from the date of his landing as aforesaid in manner and for the purposes aforsaid and shall receive the said salary of 3000 dollars or 600 pounds sterling per annum in consideration thereof and so continue until the full end and term of 5 years hereinbefore mentioned shall have expired. And it is agreed between the parties here to that if at the expiration of 5 years the said John James Baggally shall be minded and desirous of returning to Europe, then the sum of 1000 pesos shall be paid and allowed to him for the expenses of the journey, and it is also agreed between the aforesaid parties that the said sum of 600 pounds so advanced as aforesaid shall be deducted in 5 equal or proportional parts from the salary of 600 pounds or 3000 dollars during the same 5 years. And for such advance of 600 pounds and the said sum of 200 pounds allowed to the said John James Baggaly for his said outfit and voyage as aforesaid he the said John James Baggally shall enter into and give a Bond with sureties to the said don Tomás Murphy acting on behalf of the President aforesaid to the effect that the said John James Baggally shall return or repay the said 6000 pounds so advanced, if from any cause whatever this agreement shall not be performed by the said John James Baggally and the said 200 pounds shall also be returned and repaid if from any cause whatever excepting death on the said journey of voyage the said John James Baggally shall not land on the territories of the said Republic. In witness whereof the said parties to these presents have hereunto signed their names the day and year first above written. 


\section{PRÓRROGA AL CONTRATO DE JOHN JAMES BAGGALLY}

Don Bernardo Couto como presidente de la Academia de Nobles Artes de San Carlos de México y Don Juan Santiago Baggally director de grabado de la nisma Academia, declaran por ante mí, el infrascrito Secretario de ella, que la contrata que se celebró en Londres con el segundo el día treinta de abril de mil ochocientos cuarenta y seis por medio del Señor encargado de negocios de la República cerca de la corte de su Magestad Británica, y cuyo término expiró el veinte de Julio de mil ochocientos cincuenta y uno, está prorrogada por ambas partes, segun consta de la Acta de la Junta Superior de Gobierno de la Academia del dia ocho de Junio de mil ochocientos cincuenta, bajo las cláusulas y condiciones siguientes:

$1^{\circ}$ Esta renovación tiene lugar por el espacio de cinco años que comenzaron a correr el día veinte de Julio de mil ochocientos cincuenta y uno, y concluirán en igual día de mil ochocientos cincuenta y seis. Las condiciones estipuladas en la primitiva contrata ajustada en Londres continuarán rigiendo entre las partes, con todas las variaciones que se explican más adelante.

$2^{\circ}$ La asistencia personal del Director al Establecimiento será por todo el tiempo que, según los estatutos o disposiciones de la Junta de Gobierno, deba estar abierta su respectiva cátedra, a menos que por alguna ocupación concerniente al mismo Establecimiento se requiera la atención del referido Profesor en otra parte, en cuyo caso su falta de asistencia será autorizada por el Presidente de la Academia o del de la Junta Directiva.

$3^{\circ}$ Si obras que no pertenezcan a la Academia, fuera absolutamente irnposible trabajarlas en este Establecimiento, las efectuará el Director de que se trata, fuera de él, siempre que no deje por esto de dar tres horas de lección diarias, repartidas en la mañana y tarde de los días que se abran las clases en todo el año escolar:

$4^{\circ}$ En las horas, que a más de las tres de que habla el artículo anterior, trabajare en obras de la Academia ó propias, el dicho Director llamará a sus discípulos para instruirlos prácticamente en todos los pormenores del arte, fijando su atención sobre todas las dificultades que presenta y el modo de apreciarlas y resolverlas

$5^{\circ}$ El Director mencionado presentará mensualmente a la Junta de Gobier. no un informe del estado de instrucción y conducta de sus discípulos, proponiendo las reformas y mejoras que crea conducentes a su mayor adelanto y de los auxilios que necesita para el efecto.

$6^{\circ} \mathrm{El}$ mismo Director formará el catálogo de los objetos que pertenecen a su arte, y que actualmente posee la academia, haciendo las anotaciones y observaciones artísticas que crea útiles a los alumnos de la Academia a quienes estos objetos deberán serles familiares. 
$7^{\circ}$ Este Profesor dejará antes de separarse dos obras de su arte a la Academia, pagándose solamente por éstas los materiales y modelos que para la ejecución sean necesarios.

Y no habiéndose firmado en tiempo el documento relativo a esta renovación por el difunto Sr. Presidente de la Academia Javier Echeverría, la Junta Supe. rior de Gobierno en sesión de veinte y cinco de Octubre ha acordado lo verifique el actual Presidente en cumplimiento de lo cual se ha extendido por duplicado el presente documento en México a seis de Noviembre de mil ochocientos cincuenta y dos.

Bernardo Couto. Presidente (rúbrica)

Manuel Diez de Bonilla. Secretario (rúbrica)

J J Baggally (rúbrica) 


\title{
III. CONTRATO CON GEORGE AUSTIN PERIAM
}

\author{
Mexican Legation, London \\ April 2nd 1853.
}

An Agreement between Colonel Facio, Mexican Chargé d'Affaires as agent and representative of the Council of the National Academy of San Carlos, México, on the one part, and Mr. George Austin Periam on the other

$1^{\circ}$ Colonel Facio, on behalf of the Academy agree to engage Mr. G A. Periam for the Space of five years as profesor of Engraving in the said Academy, Mr. Periam to receive a salary of three thousand dollars per annum to be paid by equal monthly by payments from the day of $\mathrm{Mr}, \mathrm{G}$ A Periam's arrival at the port of Veracruz.

2" $\mathrm{Mr}$ G. A Periam undertakes to give instruction to the pupils of the Academy on all subjects, and in every known style of his Art, the instruction to be theoretical and practical to give Rules to and - to be executed by the pupils of the Academy - to point out difficulties together with the mode of over coming them, to communicate details essential and accesory, in order that the Art of Engraving may be acquired by the pupils in the greatest degree of perfection to which it has hitherto attained.

$3^{\circ}$ He moreover, engages for this purpose to give lessons in the said Academy on each day of the year (except festivals) the time of the lessons to be six hours daily, the Council determining which these hours are to be during the time of instruction the profesor undertakes to remain with his class, ocupied teaching, however, with the consent of the Academy, he may occasionally during school hours employ himself in working for his own private emolument provided this be done in the presence of his pupils, and without detriment to their advancement.

$4^{\circ}$ During the space of five years of his contract $\mathrm{Mr}$. G A Periam undertakes to engrave for the Academy two plates, one on steel, the other on copper, the Academy only paying for the materials that may be required for executing the above two plates

$5^{\circ}$ Any other plates which the council may required of him, he engages to execute in preference to any commision upon which he may be employed by private individuals or foreign corporations

$6^{\circ}$ Mr. G.A Periam hereby undertakes to defray his own travelling expenses to and from Mexico, Colonel Facio agreeing to advance him for such purpose, on the part of the Academy, six months salary, $\$ 1500$ (one thousand 
DOI: http://dx.doi.org/10.22201/iie.18703062e.1982.50\%20Tomo\%202.1159

five hunred dollars) to be deducted by equal monthly instalments from the profesor's salary, so that the reemborsement may be made in the space of two years and a half.

London 14 th april 1853

F. Facio (rúbrica)

G.A. Periam (rúbrica) 


\section{CONTRATO CON JAVIER GAVALLARI}

Manuel Larrainzar a nombre del Exmo. Sr. Presidente de la Academia de San Carlos de México, D. Bernardo Couto y el profesor D. Javier Cavallari celebran el siguiente contrato.

Art. $1^{\circ} \mathrm{El}$ Caballero Doctor Don Javier Cavallari pasará a la República Mexicana a dar lecciones en clase del profesor de arquitectura y composición en todos sus ramos con inclusión de la ingeniería civil y construcción de puentes, caminos, calzadas etc en la Academia de San Carlos.

Art. $2^{\circ}$ Las lecciones serán diarias, con excepción solamente de los dias de festividad nacional o religiosa

Art. $3^{\circ} \mathrm{El}$ profesor asistirá personalmente todos los días al Establecimiento y estará en él cada día todo el tiempo que según los estatutos o disposiciones de la Junta de Gobierno hayan de mantenerse abiertas las cátedras que sirva y deba vigilar. Corregirá diariamente las obras de sus discípulos en las horas que se le designen y guardará en todo los indicados estatutos, cumplirá los acuerdos que dicte la dicha Junta y obedecerá las órdenes de su Presidente.

Art. $4^{\circ}$ Se le dará en el edificio de la Academia una pieza que le sirva de estudio particular; pero sus discípulos tendrán libre acceso a ella para consultarle en todas las dificultades y dudas que les ocurran, así como para mejor instrucción suya en el arte. Es obligación del profesor recibirlas con bondad, hacerse respetar de ellos y comunicarles sin reserva las doctrinas y reglas de los ramos que enseña.

Art. $5^{\circ}$ Cuando para la mejor instrucción de sus alumnos sea necesario salir de la capital, previa licencia del Presidente de la Academia, para levantar planos, hacer mediciones y otros trabajos prácticos, los gastos que erogue el profesor serán de cuenta del Establecimiento.

Art $6^{\circ}$ Es obligación suya ejecutar durante el tiempo de su contrata un trabajo de su ramo para la Academia cuyo valor se considera incluso en el sueldo que disfruta.

Art. $7^{\circ}$ Es también obligación suya trabajar de preferencia, sobre cualesquiera otros encargos que tenga, las obras públicas que se le confien y se le pagarán por separado.

Art. $8^{\circ}$ El Caballero De Cavallari podrá ejercer libremente su profesión de ingeniero civil con tal que no falte a la atención de la Academia en las horas senaladas, ó que señale la Junta Superior de Gobierno en adelante, quedando libre enteramente a dicho $\mathrm{Sr}$. Cavallari el tiempo de las vacaciones anuales.

Art 9" El profesor, antes de separarse de la Academia, dejará formado un catálogo razonado de los objetos artísticos que posea el Establecimiento.

Art. $10^{\circ}$ El expresado profesor deberá ponerse en marcha para México a 
mas tardar en Noviembre o diciembre de este año de 1856, para estar en Veracruz en enero del año entrante de 1857.

Art $1^{\circ}$ Disfrutará el sueldo de tres mil pesos anuales que se le pagarán en México por meses cumplidos, empezando a correr este sueldo el día que salte en tierra en Veracruz.

Art $12^{\circ}$ La Academia da al Caballero Dr Cavallari dos mil pesos para viático de marcha y le anticipa mil por cuenta de sus sueldos, que se le deducirán: doscientos pesos en el primer año, trescientos en el segundo, trescientos en el tercero y doscientos en el cuarto

Art. $13^{\circ} \mathrm{Si}$ al cabo de los cinco años que debe durar este contrato el Dr. Cavallari hubiere sin nuevo empeño de regresar a Europa, la Academia le dará en México mil pesos para viático de regreso.

Art $1^{\circ}$ Ocho meses antes de expirar el término designado en el presente contrato, las partes contratantes se darán mutuamente aviso por escrito, si concluye al terminar los cinco años, o si se prorroga por otros cinco.

Art. $15^{\circ}$ El Caballero Dr. Cavallari recibirá en París mil y quinientos fraıcos para comprar para la Academia fotografias de monumentos notables, modelos de estereotomía y otros objetos útiles para la enseñanza.

Art $16^{\circ}$ La presente contrata durará por cinco años contados desde el mismo día del desembarco del profesor en Veracruz, y podrá ser prorrogable por otros cinco años a voluntad de ambas partes.

París, Septiembre 15 de 1856.

Manuel Larrainzar (rúbrica)

Milán 25 de Septiembre de 1856

C. Doctor Javier Cavallari (rúbrica) 


\section{PRÓRROGADELCONTRATOCONJAVIER CAVALLARI}

\section{SANTIAGO REBULL}

Director General de la Academia Nacional de Bellas Artes de San Carlos de México y el Dr. D. Javier Cavallari Director de Arquitectura de la misma Academia, declaran por ante mí el infrascrito Secretario de ella que la contrata bajo la cual el segundo ha servido la dirección de su ramo en este Establecimiento y cuyo término debe concluir en treinta y uno de diciembre del presente año, se prorroga bajo las cláusulas siguientes por común acuerdo de ambas partes contratantes y con autorización dada por el Supremo Gobierno al Director General de la Academia para celebrar este contrato como consta de la nota firmada por el Excmo. Sr. Ministro de Justicia fecha catorce de mayo del presente año y que obra en el archivo de esta Academia

$1^{\circ}$ La renovación de la contrata tiene lugar por el espacio de un año que comenzará a correr desde treinta y uno de diciembre del presente año y terminará en igual fecha del de mil ochocientos sesenta y dos.

Las condiciones estipuladas en la primera contrata ajustada en Paris entre el Director Cavallari y el Sr. D. Manuel Larrainzar a nombre del Sr. Presidente de la Academia D. Bernardo Couto el quince de septiembre de mil ochocientos cincuenta y seis, continuarán rigiendo entre las partes con sólo las variaciones que explica el presente documento.

$2^{\circ}$ El Director Cavallari asistirá personalmente todos los dias a excepción de los de fiesta nacional o religiosa al Establecimiento y estará en él cada día todo el tiempo que según el reglamento y plan de estudios de la Academia hayan de mantenerse abiertas las cátedras que sirva o deba vigilar. Corregirá diariamente las obras de sus discípulos en las horas que se le designen y guardará en todo los Estatutos de la Academia, cumplirá los acuerdos de la junta de Directores y obedecerá las órdenes del Director general de la Academia.

$3^{\circ}$ Se le dará en el edificio de la Academia una pieza que le sirva de estudio particular, pero sus discípulos tendrán libre acceso a ella para consultarle en todas las dificultades y dudas que les ocurran así como para mejor instrucción suya en el arte. Es obligación del profesor recibirlos con bondad, hacerse respetar de ellos y comunicarles sin reserva las doctrinas y reglas de los ramos que enseña

$4^{0}$ Para la mejor instrucción de los alumnos, el Sr. Cavallari hará que estos lo acompañen, previa licencia del Director general, fuera de la Capital para levantar planos, hacer mediciones, trazar caminos, construir puentes y trabajos prácticos aprovechando para esta clase de estudios todas las obras cuya dirección encomienden al Sr. Cavallari el Supremo Gobierno o algun particular y cualesquiera otras que sin estar bajo su dirección crea el Director dignas de 
ser visitadas y estudiadas Los gastos que en estos estudios erogue el Sr. Cavallari serán de cuenta del Establecimiento

5* Es obligación suya ejecutar para la Academia durante el año que durará esta contrata un trabajo de su ramo, proporcional a la duración de aquella, cuyo trabajo sea de utilidad ya para la Academia o ya para el país, el que se determinará de acuerdo entre el Sr. Director general del Establecimiento y el $\mathrm{Sr}$. Cavallari y cuyo valor se considera incluso en el sueldo que disfruta el segundo

$6^{\circ}$ Es también obligación de éste trabajar de preferencia, sobre cualesquiera otros trabajos que tenga, las obras públicas que se le confien, las que le serán pagadas por separado

7o. El Sr. Cavallari seguirá ejerciendo libremente su profesión de Ingeniero civil con tal que no falte a la atención de la Academia en las horas señaladas o que se señalaren para los estudios, quedando libre enteramente a dicho señor el tiempo de las vacaciones anuales

$8^{\circ}$ El Sr. Cavallari, antes de separarse de la Academia, dejará formado un catálogo razonado de los objetos artísticos que posea el Establecimiento.

$9^{\circ}$ El Sr. Cavallari disfrutará el sueldo anual de tres mil pesos que se le pagarán en esta capital por meses cumplidos

$10^{\circ} \mathrm{Al}$ vencimiento de esta contrata y si ésta no se renovara de común acuerdo entre las partes contratantes, la Academia dará en esta capital al Sr. Cavallari la cantidad de mil pesos para viáticos de regreso a su país

$11^{\circ}$ Ocho meses antes de esperar el término señalado en esta contrata, el $\mathrm{Sr}$ Cavallari manifestará por escrito a la Academia si concluye al terminar el año de esta prórroga o tiene voluntad de prorrogarla, en cuyo último caso la prórroga se hará por nuevo convenio mutuo entre los contratantes y por el tiempo que explicitamente se acordare

A la guarda y observancia de estas condiciones se obligan mutuamente ambas partes. Y para la debida constancia se firmó el presente documento por duplicado quedando un ejemplar en el archivo de la Academia y otro en poder del Sr Director contratante D. Javier Cavallari.

Dios, Libertad y Reforma, Méjico Mayo quince de mil ochocientos Sesenta y uno.

Santiago Rebull (rúbrica)

Dr. Javier Cavallari (rúbrica)

Jesús Fuentes y Muñiz. Secretario (rúbrica) 


\section{CONTRATO CON EUGENIO LANDESIO}

El doctor don Bernardo Couto, Presidente de la Junta Superior de Gobierno de la Academia de Nobles Artes de San Carlos de México, en nombre de dicha Academia y don Pelegrín Clavé, Director de pintura de la misma, en representación de don Eugenio Landesio, residente en Roma han celebrado la contrata siguiente:

$1^{\circ}$ Don Eugenio Landesio pasará a la República Mexicana a dar lecciones en clase de profesor de la dicha Academia de perspectiva, paisaje y principios de ornato. Las lecciones serán diarias a excepción solamente de los días de festividad nacional o religiosa.

$2^{\circ} \mathrm{El}$ profesor asistirá personalmente todos los días al establecimiento y estará en él cada día todo el tiempo que según los estatutos o disposiciones de la Junta de Gobierno hayan de mantenerse abiertas las clases que sirve y debe vigilar. Guardará en todo los indicados estatutos, cumplirá los acuerdos que dicte la dicha Junta y obedecerá las órdenes de su Presidente. Corregirá a lo menos una hora por la mañana y otra por la tarde las obras de los alumnos de perspectiva y paisaje y una hora cada noche a los de la clase de ornato.

$3^{\circ}$ Se le dará en el edificio de la Academia una pieza para que le sirva de estudio particular; pero los discípulos tendrán libre acceso a ella para mejor conocer la práctica del arte y para consultarle todas las dudas y dificultades que les ocurran. Es obligación del profesor recibirlos con bondad, hacerse respetar de ellos y comunicarles sin reserva las doctrinas y reglas de los ramos que enseña.

$4^{\circ}$ En la corrección de noche podrá hacerse ayudar por algún discípulo de su confianza siempre que así lo crea conveniente, previa anuencia del director de pintura al cual debe este profesor estar subordinado en lo general

$5^{\circ}$ Cuando sus discípulos de paisaje se hallen en disposición de salir de la capital para trabajar en el campo, podrá ausentarse con ellos previa licencia del Presidente de la Academia. En este caso dejará un discípulo de su confianza que sirva de corrector durante su ausencia.

$6^{\circ}$ Disfrutará el sueldo de mil quinientos pesos anuales que se le pagarán en México por meses cumplidos; empezando a correrle este sueldo el día que salte en tierra en Veracruz.

$7^{\circ}$ La presente contrata durará por cinco años, contados desde el mismo día del desembarco del profesor en Veracruz.

$8^{\circ}$ Es obligación suya trabajar durante dicho tiempo un cuadro para la galería de la Academia cuyo valor se considera incluso en el sueldo que disfruta. Es también obligación suya trabajar de preferencia sobre cualesquiera otros encargos que tenga, las demás obras que le pida la Academia y le pagará por 
separado

$9^{\circ}$ La Academia le dará ahora quinientos pesos en Roma para viático de venida a la República y si concluidos los cinco años de la contrata hubiere de regresar a Europa, le dará en México otros quinientos para viáticos de regreso.

$10^{\circ} \mathrm{Si}$ además necesitare a su salida habilitarse en Europa de algunos objetos de su profesión, la Academia le anticipará ahí a cuenta de sus sueldos quinientos pesos, los cuales devengará en esta forma: trescientos pesos el primer año de la contrata y doscientos el segundo.

$11^{\circ}$ El profesor antes de separarse de la Academia dejará formado un catálogo razonado de los objetos artísticos que posea el establecimiento en los ramos que él enseña.

$12^{\circ}$ Para que la presente contrata se estime obligatoria a una y otra parte, deberá ser ratificada en Roma por don Eugenio Landesio ante el excelentisimo señor Ministro Plenipotenciario de la República Mexicana en aquella corte; y el profesor deberá ponerse en marcha para México y estar en Veracruz dentro de los plazos que el mismo excelentísimo señor Ministro Plenipotenciario tenga a bien señalar con presencia de las circunstancias.

Hecho y firmado por duplicado en México a dos de mayo de mil ochocientos cincuenta y cuatro.

(firmado) Bernardo Couto. Pelegrín Clavé

Ratifico el precedente contrato fatto al Messico dal Signore Pellegrino Clavé nel mio nome. Roma 10 Guigno 1854.

(firmado) Eugenio Landesio

Es copia, Roma, noviembre 8 de 1854 